УДК:351:862.1

DOI: https://doi.org/10.32689/2618-0065-2020-1(3)-97-109

Дячкова Ольга Михайлівна, кандидат педагогічних наук, викладач кафедри психології діяльності в особливих умовах Черкаського інституту пожежної безпеки імені Героїв Чорнобиля Національного університету цивільного захисту України, вулиця Онопрієнка, 8, Черкаси, Черкаська область, 18000, тел.: 09769056 86, email: olya.diachkova@gmail.com.

ORCID: 0000-0001-5164-3522

Черкасов Олександр Олександрович, молодший науковий співробітник науково-інформаційного відділу, Український науководослідний інститут цивільного захисту, м. Київ, вул. Рибальська, 18, 01011, Україна тел.: (044)-280-18-01, e-mail.: Czerkasov@undicz.dsns.gov.ua

ORCID: 0000-0002-2523-9662

\title{
ДЕЦЕНТРАЛІЗАЦІЯ, ОСНОВНІ АСПЕКТИ ГРОМАД
}

Анотація: У статті розглянуто стан створення об'єднаних територіальних громад (ОТГ). Проаналізовано функціонування органів місцевого самоврядування та органів виконавчої влади. Розкрито ключові проблеми в процесі створення об'єднаних територіальних громад та визначено нагальні проблеми й пріоритетні напрями вдосконалення в контексті реалізації реформи по децентралізації.

Авторським колективом визначено, що заснування ОТГ вимагає утворення нового адміністративного центру для всіх міст, сіл і селищ, які увійшли до ï складу, та обов'язкове проведення виборів керуючих органів ОТГ. Крім того, у статі сформульовано структуру органів управління об'єднаних територіальних громад, повноваження яких доволі широкі: від розробки стратегії розвитку до організації благоустрою сіл і селищ, які входять до складу ОТГ.

Основними субвенціями 3 державного бюджету на розвиток ОТГ, є: субвенція на будівництво, ремонт і утримання автомобільних доріг загального користування місцевого значення; субвенція на здійснення заходів соціально-економічного характеру окремих територій; субвенція на формування інфраструктури ОТГ; субвенція на реалізацію заходів щодо розвитку системи охорони здоров'я у сільській місцевості; освітня та медична субвенція; субвенція на виплату допомоги малозабезпеченим сім'ям та ін.

У статті досліджено, що темпи формування нових об'єднаних територіальних громад випереджають темпи збільшення обсягу коштів, які виділяють 3 держбюджету на підтримку їхнього розвитку, що зумовлює нерівність умов розвитку ОТГ (в залежності від року створення громади). 
Шляхом проведення реформи децентралізації влади об'єднання територіальних громад, Уряд України мав на меті наблизити владу до жителів об'єднаних територіальних громад, а жителів - до влади 3 метою посилення їх спроможності здійснювати місцеве самоврядування та підвищення доступності якісних освітніх, медичних, культурних, адміністративних, комунальних і соціальних послуг, які отримують ті самі жителі громад.

Зроблено висновок, що у контексті реформи децентралізації в Україні, підвищення самодостатності громад, для багатьох ОТГ - наприклад тих, що не мають на своїй території великого бізнесу - може бути реалізовано тільки через об'єднання вже створених об'єднаних територіальних громад між собою.

Ключові слова: об'єднані територіальні громади, децентралізація, органи місцевого самоврядування, районні адміністрації, місцеві ради.

Diachkova Olha Mykhailivna, Candidate of Pedagogical Sciences, Lecturer of the Department of Psychology of Activity in Special Conditions of Chernobyl Heroic Institute of Fire Safety of the National University of Civil Protection of Ukraine, 8, Onopriyenka Street, Cherkasy, Cherkasy region, 18000, tel.: 09769056 86, email: @ gmail.com.

ORCID: 0000-0001-5164-3522

Cherkasov Oleksandr Oleksandrovych, Junior Researcher of the Scientific and Information Department, Ukrainian Research Institute of Civil Protection. Kiev, st. Rybalskaya, 18 01011, Ukraine tel.: (044) -280-18-01, e-mail.: Czerkasov@undicz.dsns.gov.ua

ORCID: 0000-0002-2523-9662

\section{DECENTRALIZATION, BASIC ASPECTS OF THE HUGE}

Abstract. The article deals with the state creation of amalgamated territorial community (ATC). The functioning of local self-government bodies and executive authorities is analysed. The key problems in the process of creating amalgamated territorial communities are identified and the urgent problems and priority areas of improvement identified in the context of decentralization reform.

The team of authors has determined that the ATC establishment requires the creation of a new administrative centre for all the cities, villages and settlements that are part of it, and the mandatory holding of elections of the ATC governing bodies. In addition, the article outlines the structure of governing bodies of the amalgamated territorial communities, whose powers are quite broad: from the development of a development strategy to the organization of the improvement of the villages and settlements that are part of the ATC. 
The main subventions from the state budget for the development of ATC are the followings: subsidies for construction, repair and maintenance of public roads of local importance; subsidy for the implementation of measures of socioeconomic nature of individual territories; a subsidy for the formation of an ATC infrastructure; a subsidy for the implementation of measures to develop the health system in rural areas; educational and medical subventions; and subsidy for assistance to low-income families, etc.

The article investigates that the pace of formation of new amalgamated territorial communities is outpacing the rate of increase of funds allocated from the state budget to support their development, which causes inequality in the conditions of development of ATC (depending on the year of creation of the community).

Through the reform of decentralization of territorial communities, the Government of Ukraine aimed to bring the authorities closer to the residents of the amalgamated territorial communities and the residents to the authorities in order to strengthen their ability to exercise local self-government and increase the availability of quality educational, medical, cultural, administrative, community and social services that community residents receive.

It is concluded that in the context of decentralization reform in Ukraine, increasing the self-sufficiency of communities, for many ATCs for example, those who do not have large businesses in their territory can only be realized through the unification of already established amalgamated territorial communities with each other.

Keywords: amalgamated territorial communities (ATCs), decentralization, local self-government bodies, district administrations, local councils.

Постановка проблеми. Створення об'єднаних територіальних громад (ОТГ) переважно не має підтримки з боку широких верств населення, адже люди не розуміють сам процес децентралізації, а також стикається зі спротивом 3 боку районних адміністрацій та місцевих рад, вони перешкоджають утворенню ОТГ через страх втратити робочі місця та повноваження, бо процес їх створення супроводжується переформатуванням органів влади та змінами в управлінні на користь громад. На сьогодні остаточно не врегульовано питання розподілу повноважень між органами місцевого самоврядування та органами виконавчої влади загалом, а також функцій та повноважень між місцевими радами ОТГ та районними державними адміністраціями й районними радами. Немає належно підготованих робочих кадрів та спостерігається низька кваліфікація службовців місцевого самоврядування для виконання нових функцій[1]. Як показує практика не всі органи місцевого самоврядування, як правило, готові до запровадження стратегічного планування та програмування розвитку громад. Для вирішення таких питань $є$ запровадження дієвих програм 
місцевими органами самоврядування при наданні практичної допомоги 3 боку уряду.

Аналіз останніх досліджень і публікацій. Останні п’ять років головною темою адміністративного порядку денного $\epsilon$ реформа децентралізації, яка була розпочата у 2014 р. після прийняття Концепції реформування місцевого самоврядування та територіальної організації влади в Україні (Розпорядження Кабінету Міністрів України від 01.04.2014 р. №333-p) та Плану заходів щодо реалізації названої Концепції (Розпорядження Кабінету Міністрів України від 22.09.2016 р. №688-р).2 Як уряд, так ізахідні партнери називають децентралізацію однією 3 найважливіших реформ в Україні після 2014 року. Оскільки процес лише почався, робити висновки про його успішність зарано. Втім, наукові дослідження іноземного досвіду звертають увагу на неоднозначність результатів децентралізації у різних країнах. Одним з факторів, який може вплинути на те, наскільки успішною буде реформа, є розподіл їі результатів. [3].

Виклад основного матеріалу дослідження. Територіальна громада «жителі, об'єднані постійним проживанням у межах села, селища, міста, що є самостійними адміністративно-територіальними одиницями, або добровільне об'єднання жителів кількох сіл, що мають єдиний адміністративний центр». Основними iii ознаками є спільна територія існування, наявність спільних інтересів місцевого значення, соціальна взаємодія членів громади в процесі забезпечення цих інтересів, психологічна самоідентифікація кожного члена 3 громадою, спільна комунальна власність, сплачування комунальних податків [4].

Конституційна норма встановлює, що матеріальною та фінансовою основою місцевого самоврядування $є$ рухоме й нерухоме майно, доходи місцевих бюджетів, інші кошти, земля, природні ресурси, що є у власності територіальних громад сіл, селищ, міст, районів у містах, а також об'єкти їхньої спільної власності, що перебувають в управлінні районних і обласних рад (стаття 142 Конституції України) [5]. Кінцевою метою децентралізації передбачається створення спроможних територіальних громад унаслідок передачі значних повноважень та ресурсів від державних органів органам місцевого самоврядування. За цих умов зростає роль територіальних громад місцевого самоврядування у соціально-економічному розвитку країни [6].

Таким чином ми бачимо, що станом на 10 серпня 2019 року в Україні сформовано 936 об’єднаних територіальних громад (ОТГ), 3 яких 55 очікують рішення ЦВК про призначення на їх території перших місцевих виборів. До загальної кількості ОТГ входять і ті, які утворилися з центрами у містах обласного значення - 75 територіальних громад приєдналися до 34 міст обласного значення. Ще 6 таких міст розпочали процедури приєднання довколишніх громад. У Міністерстві назвали п’ятірку регіонів-лідерів у рейтингу формування спроможних громад - Житомирська, Чернігівська, 
Дніпропетровська, Запорізька та Хмельницька області. Останні місця рейтингу поки незмінно посідають Закарпатська, Кіровоградська, Вінницька, Київська, Львівська області. На 100\% покриті об'єднаними громадами території 20 районів в Україні. Території 158 районів покриті ОТГ на рівні більше 50\%. Ще 199 районів покриті спроможними громадами на рівні 149\%. Дещо зменшилася кількість районів, де не створено жодної ОТГ. Таких налічується 88. Найбільше таких районів у Харківській області - 14; в Одеській області - 11; Кіровоградській - 10; Київській - 9; Закарпатській - 7; у Вінницькій, Донецькій та Херсонській областях - по 6 районів. Крім того, в об'єднаних громадах активно створюються опорні школи. На сьогодні їх налічується 351 та 568 їх філій, в яких навчається більше 157 тис дітей. Закуплено близько тисячі шкільних автобусів, які забезпечують підвіз дітей до опорних закладів. Зросла кількість громад, які використовують ще один важливий інструмент для розвитку - співробітництво територіальних громад. Дані Моніторингу свідчать, що 1100 громад уклали 451 договір про міжмуніципальне співробітництво. Цей дієвий інструмент найбільш активно використовують у Полтавській, Вінницькій областях і проявляють пасивність в Миколаївській, Одеській областях. [7].

Утворення ОТГ передбачає створення нового адміністративного центру для всіх міст, сіл і селищ, які увійшли до іiі складу, та проведення виборів керуючих органів ОТГ (голови і депутатів ради ОТГ, а також старост, які представлятимуть інтереси села - за умови, що кількість його мешканців становить більш як 50 осіб - чи кількох сіл в органах управління ОТГ). Кількість депутатів у раді залежить від чисельності виборців (до 1 тис. виборців - 12 депутатів; від 1-3 тис. виборців - 14 депутатів; 3-5 тис. виборців - 22 депутати; 5-20 тис. виборців - 26 депутатів і т.д.). Раду підпорядковано виключно громаді. Безпосереднє керівництво ОТГ (зокрема й управління фінансами) здійснює створений радою виконавчий комітет. До його складу входять голова ради, його заступник з питань діяльності виконавчих органів ради, секретар виконкому, керівники відділів та управлінь, секретар ради, старости, інші особи (підприємці, громадські активісти та ін., крім депутатів місцевої ради). Рада та виконком перебувають на одному ієрархічному щаблі, але до того ж виконком підзвітний i підконтрольний раді. Тобто в разі прийняття виконкомом рішення, яке суперечить законодавству, рада має право його скасувати.

Рада також може створювати власні органи для управління освітою, охороною здоров'я, містобудівною діяльністю тощо, які підпорядковано виконавчому комітету. 


\section{Умовна структура органів управління ОТГ}

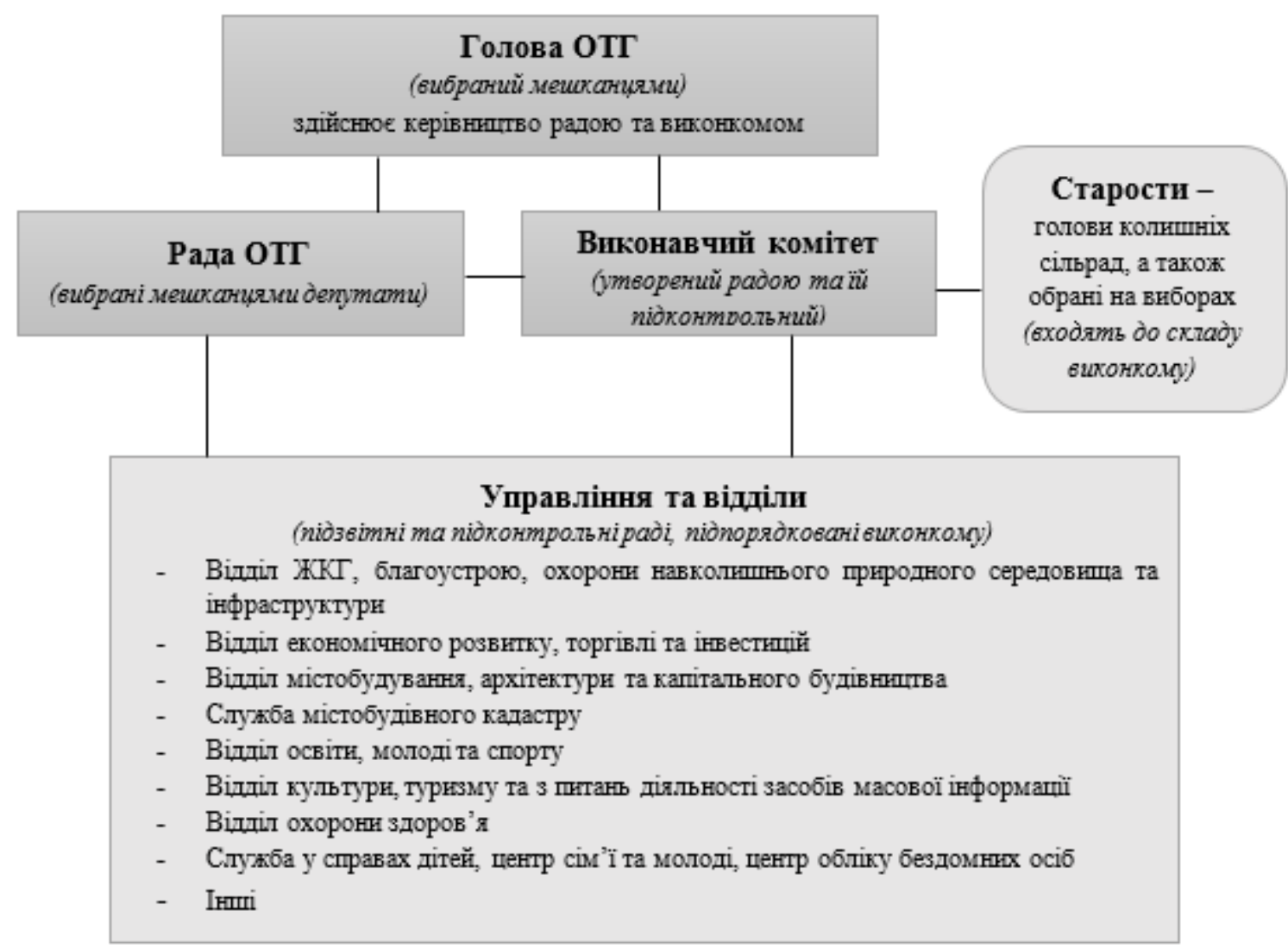

Повноваження керівних органів ОТГ

Повноваження органів ОТГ доволі широкі: від розробки стратегії розвитку до організації благоустрою сіл і селищ, які входять до складу ОТГ. Зокрема рада затверджує бюджет ОТГ; утворює виконавчий комітет; встановлює місцеві податки і збори; визначає, яким буде соціальноекономічний і культурний розвиток ОТГ, та ін. Виконавчий комітет своєю чергою забезпечує виконання бюджету ОТГ; координує діяльність відділів, управлінь, комунальних підприємств, установ та організацій ОТГ; має право змінювати/скасовувати акти підпорядкованих йому відділів, управлінь та їхніх посадових осіб тощо. Розвиток ОТГ повинен узгоджуватись із загальною стратегією розвитку відповідної області для формування потужних конкурентоспроможних регіонів і зрівноваження регіонів у межах країни. На практиці ОТГ, які «вписують» свій розвиток у регіональні стратегії, мають змогу отримати фінансування з обласних бюджетів під програми регіонального розвитку (наприклад, у Львівській області 3 обласного бюджету на конкурсних засадах співфінансують мікропроекти регіонального розвитку. Перевагу отримують ті, які відповідають стратегії розвитку регіону). 
Варто зазначити, що в результаті права на добровільність об'єднання громад $18 \%$ території країни не охоплено перспективними планами формування ОТГ. Найгірша ситуація в громадах Закарпатської, Одеської, Київської, Вінницької та Полтавської областей, в яких проблеми виникають ще на етапі формування плану. Причини - небажання місцевого керівництва втратити владу в багатих громадах (тобто тих, які мають ресурси наповнення місцевих бюджетів) через об'єднання з біднішими; неможливість чітко визначити критерії для об' єднання громад (як, наприклад, на Закарпатті, де $\epsilon$ громади, розташовані на гірських, низинних, а також і на гірських, i на низинних територіях (з переважанням одних або інших громад), що накладає свою специфіку на загальний шаблон об'єднання) і т.ін. Проблеми, які перешкоджають просуванню реформи децентралізації та розвитку ОТГ, умовно можна поділити на законодавчі та внутрішні. Для формування спроможних громад на рівні можновладців потребують врегулювання (через прийняття відповідних законів) питання, які стосуються: адміністративнотериторіального устрою (зокрема порядку утворення та ліквідації адміністративно-територіальних одиниць, встановлення і зміни їх меж тощо); служби в органах місцевого самоврядування (йдеться про надання ОМС більшої автономії у визначенні умов оплати праці для залучення до ОМС професійних кадрів); містобудівної діяльності (в частині просторового планування в ОТГ, зокрема щодо можливості ОТГ розпоряджатися землями, які перебувають на її території, за межами населених пунктів); добровільного об'єднання територіальних громад (зокрема вдосконалення процедури затвердження перспективних планів формування територіальних громад i надання права затверджувати їх виключно КМУ, а не облрадам, на рівні яких лобіюють свої інтереси місцеві олігархи, створюючи ОТГ «під себе»). Серед перешкод розвитку ОТГ внутрішнього характеру домінують: нестача фінансових ресурсів, брак кваліфікованих кадрів, міграція мешканців ОТГ за iii межі, неофіційна зайнятість, низька активність жителів у вирішенні питань функціонування громади та ін. Також слід врахувати недореформований освітній сектор та сектор охорони здоров'я - багато нагальних проблем в цих сферах лягли на плечі ОТГ.

Найвагомішими/«найдорожчими» субвенціями, які виділяють 3 державного бюджету на розвиток ОТГ, були і залишаються: субвенція на будівництво, реконструкції, ремонт і утримання автомобільних доріг загального користування місцевого значення; субвенція на здійснення заходів щодо соціально-економічного розвитку окремих територій; субвенція на формування інфраструктури ОТГ; субвенція на реалізацію заходів, спрямованих на розвиток системи охорони здоров'я у сільській місцевості, та деякі інші. Крім того, з держбюджету передають місцевим бюджетам освітню та медичну субвенції, субвенцію на виплату допомоги малозабезпеченим сім'ям, субвенцію на надання пільг і житлових субсидій населенню на оплату природного газу і т.ін. 
Сума державної фінансової підтримки розвитку територіальних громад (зокрема і ОТГ, які функціонують) - субвенцій, які скеровували на розвиток, та деяких інших розвиткових фінінструментів - за період 2015-2018 років зросла в 4.7 разу і 2018 року перевищила 17 млрд грн. Однак темпи формування нових ОТГ випереджають темпи збільшення обсягу коштів, які виділяють 3 держбюджету на підтримку їхнього розвитку. Це спричиняє до нерівності умов розвитку тих ОТГ, які утворено в 2015-2016 роках, і тих, які утворено пізніше.

\section{Структура ОТГ за дотаційністю ,\%}

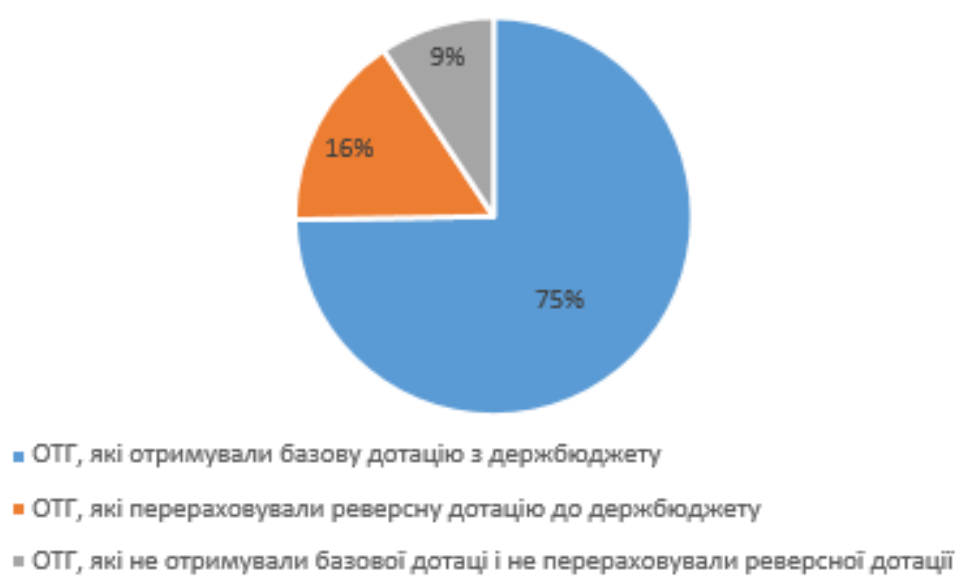

Реформа децентралізації триває, щоправда, суттєво відстає від урядового графіка, оскільки на початок 2019 року створено тільки дві третини запланованих ОТГ, якими охоплено лише третину території країни. Тому навряд чи до місцевих виборів-2020 вся територія України буде покрита ОТГ, як планувалося на початку реформи. Що ж до підвищення спроможності та самодостатності громад, то для багатьох ОТГ - тих, які не мають на своїй території великого бізнесу - воно може бути реалізовано тільки через об’єднання (укрупнення) вже створених ОТГ між собою [8].

На ряду з цим, проаналізувавши значну кількість літературних джерел, можемо зробити такі висновки:

1) існує загальне зрушення від видатних одинаків до колективного лідерства;

2) лідерство більше не асоціюється з індивідами на вершині ієрархії, а скоріше стає більш розподіленим серед всіх учасників;

3) критична вимога для ефективного лідерства пов'язана 3 формуванням інтенсивного колективного розуму і одночасно зі створенням підтримуючої мережевої культури Спільноті практик;

4) форма лідерства має бути адаптована і залежати від типу активності і розв'язуваної проблеми, тобто бути більш ситуативно залежною;

5) лідерство починає сильніше залежати від характеристик і очікувань взаємодіючих суб'єктів;

6) нове лідерство передбачає наявність прямої розумової взаємодії; 
7) всередині колективного лідерства виникає нова категорія лідерства перехідне лідерство.

Безумовно, реалізація потенціалу залучення інтелектуалів у комунікативні практики учасників Спільноти практик, знаходиться в залежності від об'єктивних умов - ступеня готовності центральної влади та суспільства до змін, відкритості суспільства або демократичності політичної системи, доступності каналів електронної комунікації тощо. Однак інтеграція професійних виробників ідей в практики місцевого самоврядування за допомогою участі у віртуальному спілкуванні з активістами територіальних громад і прихильниками громадських рухів сьогодні все частіше впливає на формування репертуару колективних дій, інтенсифікацію спілкування i розвиток активістського середовища, а в перспективі формування та функціонування об’єднаних територіальних громад [9].

Пріоритетними цілями галузей інфраструктури повинні обиратись забезпечення надійності, якості, достатності і збалансованості ï послуг для всіх груп споживачів у регіонах. Особливістю кластерних форм організації в інфраструктурній галузі регіону повинно стати не просто поєднання підприємств за принципом спрямованості і спорідненості їх діяльності і кооперативних зв'язків і співпраці, а й спрямованістю на вирішення спільних інфраструктурних регіональних проблем. Необхідним стає поглиблення співпраці заради дотримання принципів суспільно-соціального корпоративного управління, корпоративної і соціальної відповідальності, корпоративної організаційної культури і поширенню їх у сферах діяльності на території регіону, що збільшує інтелектуальний і духовний потенціал розвитку. Застосування кластерного підходу до поглиблення і розбудови процесів співпраці і партнерства розширить інституційний простір розвитку регіонів і сформує дієвий соціальний інституційний механізм управління розвитком його інфраструктури - механізм соціальної співпраці, соціального партнерства і соціального реформування як складової частини кластерної моделі розвитку регіону [10].

Започаткувавши у рамках реформи децентралізації влади об'єднання територіальних громад, Уряд України мав на меті посилення їх спроможності здійснювати місцеве самоврядування, а саме вирішувати питання місцевого значення. Водночас у відповідних документах йдеться більшою мірою про фінансово-ресурсну спроможність $[11 ; 12]$, а діяльнісним аспектам їх функціонування, що відносяться до сфери дієздатності територіальних громад, загалом приділяється мало уваги.

Зауважимо, що категорія «дієздатність» змістовно $\epsilon$ вужчою за «спроможність» та має два значення: 1) здатність до дії, діяльності; 2) право на здійснення яких-небудь юридичних дій і обов'язок нести відповідальність за свої вчинки [13]. Відтак, дану категорію слід використовувати для позначення діяльнісних та правових аспектів функціонування територіальної громади. Під дієздатністю територіальної громади ми розуміємо здатність 
жителів села чи добровільного об'єднання у сільську громаду жителів кількох сіл, селища та міста брати участь у місцевому самоврядуванні, зокрема у процесах розроблення та ухвалення управлінських рішень на місцевому рівні, ініціювати через створені ініціативні групи перед органами місцевого самоврядування вирішення актуальних питань місцевого значення, або безпосередньо їх вирішувати через органи самоорганізації населення та місцеві об'єднання громадян. Так, говорячи про дієздатність територіальної громади, ми звертаємо увагу на розширення участі іiі членів у місцевому самоврядуванні, активізацію громадської ініціативи, загалом - зміцнення місцевої демократії. Як і будь які процеси, об'єднання територіальних громад має дуалістичну природу. Поряд з його позитивними наслідками, які вже відомі на сьогодні, можуть виникнути й певні ризики щодо їх подальшої дієздатності, про що практично не говорять в сучасній Україні. Серед дослідників ризиків від такого об'єднання слід назвати О.Бобровську та Є. Жадана, які встановили соціальні ризики [14]

Однією 3 головних вимог Свросоюзу та Міжнародного валютного фонду при наданні кредитів та фінансової допомоги і просування по шляху євроінтеграції $є$ децентралізація влади в Україні на зразок розвинутих демократичних країн Свропи. Децентралізація влади - це передача від державної влади до місцевої багатьох функцій та відповідно фінансових ресурсів. Це, зокрема, охорона здоров'я та освіта, можливість створення муніципальної міліції, відділів містобудування, соціального захисту і т. д. Це все за прикладом світового досвіду повинно позитивно вплинути на якість життя членів громади та покращити рівень життя в країні в цілому [15]. При створенні об'єднаних територіальних громад ініціатори повинні виконуватись наступні вимоги [16]: 1. У складі об'єднаної територіальної громади не може існувати іншої територіальної громади, що має свій представницький орган місцевого самоврядування. 2. Територія об'єднаної територіальної громади має бути нерозривною, межі визначаються за зовнішніми межами юрисдикції рад територіальних громад, що об'єдналися. 3. Якість та доступність публічних послуг, що надаються в об'єднаній територіальній громаді, не можуть бути нижчими, ніж до об’єднання. 4. Зони доступності потенційних адміністративних центрів спроможних територіальних громад визначають 3 урахуванням доступності послуг у відповідних сферах, зокрема часу прибуття для надання швидкої медичної допомоги у невідкладних випадках та пожежної допомоги, що не має перевищувати 30 хвилин. [17].

\section{Висновки та рекомендації:}

1. Перехід до самостійної адміністративно-територіальної одиниці, або добровільного об'єднання населення безумовно являється пріоритетним напрямком розвитку у суспільстві та підтвердження рівності населення при організації місцевого самоврядування. 
2. Ефективність - це процеси децентралізації та реформації місцевого самоврядування в Україні, що обумовлюють необхідність запровадження сучасних та системних підходів, концепцій і технологій муніципального менеджменту.

3. Для України надзвичайно перспективним $є$ напрямок світового досвіду по шляху євроінтеграції є децентралізація влади в Україні на зразок розвинутих демократичних країн Європи.

4. Враховуючи викладений матеріал вважаємо за доцільним проведення аналітичної та дослідної роботи стосовно децентралізації, при цьому цілями галузей інфраструктури повинні обиратись забезпечення надійності, якості, достатності і збалансованості послуг для всіх груп споживачів у регіонах.

\section{Jimepamypa:}

1. Віктор Кузуб. Пять проблем децентрализации, или как стать хозяином в своем городе. Конституційний процес в Україні: політико-правові аспекти. № 11 (43). 2017. С. 37-38. URL: https://www.pravda.com.ua/rus/columns/2017/11/16/7162180/

2. Катерина Вознюк. Перспективність об'єднання територіальних громад. $\begin{array}{lllllll}\text { Юридична газета. № } 16 & \text { (670). 2019. URL: http://yur- }\end{array}$ gazeta.com/publications/practice/inshe/perspektivnist-obednannya-teritorialnih-gromad.html

3. Федорів П. Не лише децентралізація: навіщо Україні політика територіального вирівнювання [Електронний ресурс] / П. Федорів // MISTOSITE. - ГО «Центр дослідження суспільства/CEDOS».- 2018. - Режим доступу: https://mistosite.org.ua/articles/nelyshedetsentralizatsiia-navishcho-ukraini-potribna-polityka-terytorialnohovyrivniuvannia?locale $=\mathrm{uk}$

4. Політологічний енциклопедичний словник / уклад.: [Л. М. Герасіна, В. Л. Погрібна, І. О. Поліщук та ін.]; за ред. М. П. Требіна. - Х. : Право, 2015. - 816 с.

5. Даугуль В., Алексенко А. Актуальні питання використання земель сільськогосподарського призначення органами місцевого самоврядування / В. Даугуль, А. Алексенко. - Х. : Фактор, 2018. - 176 с.

6. Куценко Т. Ф. Об'єднані територіальні громади в Україні: короткий аналітичний огляд. Економіка та держава. 2017. № 3. С. 64-70

7. Децентралізація дає можливості. «Поки одні громади думають, чи варто... ОТГ пожинають плоди реформи». URL: https://decentralization.gov.ua/

8. Децентралізація: коротко про головне. URL: http://cost.ua/news/698detsentralizatsiya-korotko-pro-holovne

9. Алюшина Н. О. Колективне лідерство спільноти практик - каталізатор розвитку та співробітництва об’єднаних територіальних громад // Науково-практичне забезпечення розвитку та співробітництва об'єднаних територіальних громад: матеріали наук.-практ. конф. за міжнар. участю, м. Дніпро, 24 жовтня - 24 листопада 2016 р. / за заг. ред. Ю. П. Шарова. - Д. : ДРІДУ НАДУ, 2016. С. 11-13.

10. Бобровська О. М. Кластеризація інфраструктури територіальних громад як чинник сталого розвитку місцевого самоврядування // Науково-практичне забезпечення розвитку та співробітництва об’єднаних територіальних громад: матеріали наук.-практ. конф. за міжнар. участю, м. Дніпро, 24 жовтня - 24 листопада 2016 р. / за заг. ред. Ю. П. Шарова. - Д. : ДРІДУ НАДУ, 2016. С. 23-26.

11. Про затвердження Методики формування спроможних територіальних громад : постанова Кабінету міністрів України від 8 квіт. 2015 p. № 214. URL: http://zakon0.rada.gov.ua/laws/show/214-2015-\%D0\%BF 
12. Про схвалення Концепції реформування місцевого самоврядування та територіальної організації влади в Україні : розпорядження Кабінету міністрів України від 1 квіт. 2014 p. № 333-p [Електронний ресурс]. - Режим доступу : http://zakon5.rada.gov.ua/laws/show/333-2014-\%D1\%80

13. Великий тлумачний словник сучасної української мови (з дод. і допов.) / Уклад. і голов. ред. В. Т. Бусел. - К., Ірпінь. : ВТФ «Перун», 2005. - 1728 с.

14. Бобровська О. Ю. Передумови реформування соціально-економічної сфери об'єднання територіальних громад / О. Ю. Бобровська Є. В. Жадан // Публічне адміністрування: теорія та практика : Електронний зб. наук. праць. - 2015. - № 01(13). Режим доступу : http://www.dbuapa.dp.ua/zbirnik/2015-01(13)/18.pdf

15. В єдності - сила громади (про об'єднання громад Баштанського району) // [Електронний ресурс]. - Режим доступу : http://gazetabashtanka.blogspot.ru.

16. Закон України «Про добровільне об'єднання територіальних громад» №1788/01/05-60/3-15 від 28.04.2015 року // [Електронний ресурс]. - Режим доступу: http://zakon4.rada.gov.ua.

17. Науково-практичне забезпечення розвитку та співробітництва об'єднаних територіальних громад // Матеріали науково-практичної конференції за міжнародною участю (30 жовтня - 30 листопада 2018 р., м. Дніпро).

\section{References:}

1. Kuzub, V. (2017). Pyat problem detsentralizatsii, ili Kak stat khozyainom v svoem gorode [Five Problems of Decentralization, or How to Become a Host in Your City]. www.pravda.com.ua. Retrieved

from https://www.pravda.com.ua/rus/columns/2017/11/16/7162180/ [in Ukrainian].

2. Voznyuk, K. (2019). Perspektyvnist obiednannia terytorialnykh hromad [The prospect of uniting territorial communities]. Yurydychna hazeta - Legal newspaper, 16(670). Retrieved from http://yur-gazeta.com/publications/practice/inshe/perspektivnist-obednannya-teritorialnihgromad.html [in Ukrainian].

3. Fedoriv, P. (2018). Ne lyshe detsentralizatsiia: navishcho Ukraini polityka terytorialnoho vyrivniuvannia [It's not only about decentralization: why Ukraine has a territorial equalization policy]. mistosite.org.ua. Retrieved from https://mistosite.org.ua/articles/nelyshedetsentralizatsiia-navishcho-ukraini-potribna-polityka-terytorialnohovyrivniuvannia?locale=uk [in Ukrainian].

4. Herasina, L. M., Pohribna, V. L., Polischuk, I. O., et al. (2015). Politolohichnyi entsyklopedychnyi slovnyk [Political Science Encyclopedic Dictionary]. Kharkiv: Pravo [in Ukrainian].

5. Dauhul, V., Aleksenko, A. (2018). Aktualni pytannia vykorystannia zemel silskohospodarskoho pryznachennia orhanamy mistsevoho Samovriaduva [Topical issues of agricultural land use by local governments]. Kharkiv: Factor [in Ukrainian].

6. Kutsenko, T. F. (2017). Obiednani terytorialni hromady v Ukraini: korotkyi analitychnyi ohliad [United Territorial Communities in Ukraine: a Brief Analytical Review]. Ekonomika ta derzhava - Economic and state, 3, 64-70 [in Ukrainian].

7. «Poky odni hromady dumaiut, chy varto... OTH pozhynaiut plody reformy», Viacheslav Nehoda prokomentuvav Monitorynh detsentralizatsii ["While some communities are thinking if it's worth it... UTCs are reaping the benefits of reform," Vyacheslav Negoda commented on Decentralization Monitoring]. (2019). decentralization.gov.ua. Retrieved from https://decentralization.gov.ua/news/11425 [in Ukrainian].

8. Decentralizacia: korotko pro holovne [Decentralization: briefly about the main thing]. (2019). cost.ua. Retrieved from http://cost.ua/news/698-detsentralizatsiya-korotko-pro-holovne [in Ukrainian]. 
9. Aliushyna, N. O. (2016). Kolektyvne liderstvo spilnoty praktyk - katalizator rozvytku ta spivrobitnyctvo obednanykh terytorialnykh hromad [Collective leadership of the community of practices is a catalyst for the development and cooperation of united territorial communities]. Naukovo-praktychne zabezpechennia rozvytku ta spivrobitnytstva obednanykh terytorialnykh hromad - Scientific and practical support of development and cooperation of the united territorial communities: Proceedings of scientific practical Conference for the international participation. (pp 11-13). Dnipro: DRIDU NADU [in Ukrainian].

10. Bobrovska, O. Yu. (2016). Klasterizatsia infrastrukturyeritorialnykh hromad iak chynnyk staloho rozvytku tamistsevoho samovriaduvannia [Clustering of infrastructure of territorial communities as a factor of sustainable development of local self-government]. Naukovo-praktychne zabezpechennia rozvytku ta spivrobitnytstva obednanykh terytorialnykh hromad - Scientific and practical support of development and cooperation of the united territorial communities: Proceedings of scientific practical Conference for the international participation. (pp 23-26). Dnipro: DRIDU NADU [in Ukrainian].

11. Postanova Kabinetu Ministriv Ukrainy "Pro zatverdgennia metodyky formuvanniaspromognykh terytorialnykh hromad” : vid 8 kvitnia 2015 r., № 214 [Resolution of the Cabinet of Ministers of Ukraine "On approval of the Methodology of forming capable territorial communities” from April 8, 2015, № 214]. (n.d.). zakon.rada.gov.ua. Retrieved from http://zakon0.rada.gov.ua/laws/show/214-2015-\%D0\%BF [in Ukrainian].

12. Rozporiadgennia Kabinetu Ministriv Ukrainy "Pro skhvalennia Kontsepcii reformuvannia mistsevoho samovriaduvannia ta terytorialnoi orhanizacii vlady v Ukraini” : vid 1 kvitnia 2014 r., № 333-r [Order of the Cabinet of Ministers of Ukraine "On approval of the Concept of reforming local self-government and territorial organization of government in Ukraine” from April 1, 2015, № 333-p]. (n.d.). zakon.rada.gov.ua. Retrieved from http://zakon5.rada.gov.ua/laws/show/333-2014-\%D1\%80 [in Ukrainian].

13. Velykyi tlumachnyi slovnyk suchasnoi ukrainskoimovy [A great explanatory dictionary of modern Ukrainian]. (2005). Irpin: VTF «Perun» [in Ukrainian].

14. Bobrovska, O. Yu. (2015). Peredumovy reformuvannia socialno-ekonomichnoi sfery obednannia terytorialnukh hromad [Prerequisites for reforming the socio-economic sphere of territorial community unification]. Publichne administratuvannia: teoria ta praktyka - Public Administration: Theory and Practice, 01(13). Retrieved from http://www.dbuapa.dp.ua/zbirnik/2015-01(13)/18.pdf [in Ukrainian].

15. V iednosti - syla hromady (pro obiednannia hromad Bashtanskoho raionu) [In Unity is Community Strength (About uniting the Bashtansky District communities)]. (n.d.). gazetabashtanka.blogspot.ru Retrieved from http://gazetabashtanka.blogspot.ru [inUkrainian].

16. Zakon Ukrainy «Pro dobrovilne obiednannia terytorialnykh hromad» : vid 28 kvitnia 2015 roku, № 1788/01/05-60/3-15 [The Law of Ukraine “On voluntary union of territorial communities” from April 28, 2015, № 1788/01/05-60/3-15]. (n.d.). zakon.rada.gov.ua. Retrieved from https://zakon.rada.gov.ua/laws/show/157-19 [inUkrainian].

17. Naukovo-praktychne zabezpechennia rozvytku ta spivrobitnytstva obednanykh terytorialnykh hromad [Scientific and practical support for the development and cooperation of the united territorial communities]. (2018) Proceedings of scientific practical conference with international participation. Dnipro: DRIDU NADU [in Ukrainian]. 